\title{
PERILAKU KONSUMSI KOMUNITAS PENGAJIAN AL-IKHLAS RUNGKUT SURABAYA
}

\author{
Elsha Sophia \\ Mahasiwa Program Studi S1 Ekonomi Islam - Fakultas Ekonomi dan Bisnis - Universitas \\ Airlangga \\ Email : elsha.sophia13@gmail.com \\ Muhammad Nafik H.R. \\ Departemen Ekonomi Syariah - Fakultas Ekonomi dan Bisnis - Universitas Airlangga \\ Email : manhard999@yahoo.com
}

\begin{abstract}
:
The main purpose of these research is to get the information about recitation's affection on the consumption behavior of Al-lkhlas Rungkut Surabaya recitation community.

This research use qualitative case study explanatory method. Data collection was done by interviewing, observating, and documentating on the Al-lkhlas Rungkut Surabaya recitation community.

The result obtained is recitation activity have an impact on consumption behavior undertaken by the majority of Al-Ikhlas Rungkut Surabaya recitation community with giving more attention to the appropriate Islamic consumption behavior, namely: 1) Halal and thayyib, 2) Not improvident and extravagant, and 3) balancing the consumption in the world and afterlife. Some members can be said to be improvident and extravagant because of their excessive consumption of goods and use the goods not according to their function, and eventually became redundant. It happens because they can not control their desire really well, although it does not harm them. Then, the behavior of consumption in order to fulfill the dharuriyyat, hajiyyat, and tahsiniyyat for the sake of religion, life, intelligence, descent, and property's maintenance have also been able to reach and fulfilled in a good way even though it is not perfect.
\end{abstract}

\section{Keywords : consumption behavior, islamic consumption, maqashid sharia, recitation.}

\section{PENDAHULUAN}

\section{A. Latar Belakang Masalah}

Manusia adalah makhluk Allah yang diciptakan sebagai hamba dan khalifah. Tujuan utama manusia sebagai hamba Allah di dunia ini adalah untuk beribadah kepada Allah SWT. Sebagaimana yang terkandung dalam Alqur'an surat Adh-Dhariyat ayat 56. Tujuan kedua yaitu menjadikan manusia sebagai khalifah yang dijelaskan dalam surat AlBaqarah ayat 30 .

Kewajiban manusia adalah beribadah kepada Allah dengan cara menjalankan perintah dan menjauhi
laranganNya baik dalam hal hubungannya dengan Allah dan hubungannya dengan sesama manusia serta alam sekitar. Salah satu bentuk ibadah kepada Allah ialah dengan menuntut ilmu. Suatu wujudan menuntut ilmu ialah dengan mempelajari, mengetahui dan memahami tentang semua hal yang telah diatur oleh Allah dalam Al-Qur'an dan Hadits.

Pendidikan non-formal secara konsepsional sifatnya sangat luas yang tidak terikat oleh waktu dan tempat serta kurikulum atau aturan-aturan formal lainnya. Salah satu menuntut ilmu melalui 
pendidikan non-formal ialah dengan adanya forum pengajian ibu-ibu yang tujuannya untuk meningkatkan kualitas pendidikan ibu-ibu, sekaligus mengembangkan sifat-sifat sosial dan sebagai lahan pembinaan aqidah Islam.

Dalam Islam, seorang Muslim memiliki tiga macam kebutuhan menurut ghazali (Sukadi, 2011 : 27-28) yaitu, kebutuhan Al-Dharuriyyah yang merupakan kebutuhan dasar demi terjaganya kehidupan manusia. Kedua, Al-Hajiyyah yaitu kebutuhan kesenangan atau kenyamanan dan penyempurnaan dari kebutuhan Al-Dharuriyyah. Terakhir yaitu At-Tahsiniyyah yang merupakan kebutuhan akan kemewahan serta penyempurnaan dari kebutuhan sekunder.

$\begin{array}{lrr}\text { Manusia melakukan } & \text { konsumsi } \\ \text { dalam rangka } & \text { untuk memenuhi } \\ \text { kebutuhannya. } & \text { Menurut } & \text { Hidayat }\end{array}$
(2010:230), tujuan konsumsi dalam Islam adalah untuk mewujudkan maslahah duniawi dan ukhrawi. Maslahah duniawi ialah terpenuhinya kebutuhan dasar manusia seperti makanan, minuman, pakaian, perumahan, kesehatan. Kemaslahatan akhirat ialah terlaksananya kewajiban agama seperti shalat dan haji. Artinya makan dan minum agar bisa beribadah kepada Allah SWT.

Menurut Al-Ghazali (Karim, 2007:62), kesejahteraan (maslahah) dari suatu masyarakat tergantung kepada pencarian dan pemeliharaan lima tujuan dasar: agama (al-dien), hidup atau jiwa (nafs), keluarga atau keturunan (nasl), harta atau kekayaan (maal), dan intelek atau akal (aql). la menitik beratkan bahwa sesuai tuntutan wahyu "kebaikan dunia ini dan akhirat (maslahat al-din wa al-dunya) merupakan tujuan utamanya".

Al-Qur'an mengingatkan manusia agar tidak hanyut dan tenggelam dalam kehidupan yang materialistic dan hedonistic. Bukan berarti Islam melarang manusia menikmati kehidupan dunia. Allah SWT telah memberikan segalanya kepada kita, namun Allah SWT juga mengingatkan kita agar tidak berbuat boros dan berlebih-lebihan. Termasuk dalam israf adalah watak manusia yang terus ingin menukar dan mengganti alat yang dikonsumsi, padahal fungsi dan kualitas barang yang lama masih bagus (Hidayat, 2010:236). Terutama di kalangan kaum hawa atau ibu-ibu yang berperan sebagai pengendali keuangan dalam rumah tangga dan berpotensi besar berperilaku konsumtif dalam hal berbelanja segala kebutuhan rumah tangga dan kebutuhan pribadinya. Mereka cenderung sulit membedakan yang mana kebutuhan dan yang mana keinginan.

Oleh karena itu adanya sebuah komunitas pengajian diharapkan mampu memberi arahan yang baik melalui pembelajaran tentang ilmu-ilmu agama Islam sebagai penguat aqidah termasuk dalam bagaimana cara pengamalan berperilaku konsumsi yang baik agar tidak menjadi seseorang yang boros dan berlebih-lebihan yang dilarang oleh Allah. 
Maka dari itu penulis tertarik untuk melakukan penelitian guna mengetahui bagaimana perilaku konsumsi anggota komunitas pengajian Al-Ikhlas cabang Rungkut Surabaya.

\section{B. Rumusan Masalah}

Rumusan masalah dalam penelitian ini adalah bagaimana dampak pengajian pada perilaku konsumsi di komunitas pengajian Al-lkhlas Rungkut Surabaya?

\section{Tujuan Penelitian}

Tujuan dari penelitian ini adalah untuk mengetahui dampak pengajian pada perilaku konsumsi di komunitas pengajian Al-Ikhlas Rungkut Surabaya.

\section{LANDASAN TEORI}

\section{A. Hakikat Penciptaan Manusia}

Menurut Achmadi (2005: 61-63) tujuan utama manusia sebagai hamba Allah di dunia ini adalah untuk beribadah kepada Allah SWT. Sebagaimana yang terkandung dalam Al-qur'an surat AdhDzariyaat ayat 56 :

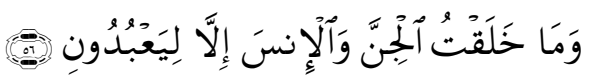

"Dan aku tidak menciptakan jin dan manusia melainkan supaya mereka mengabdi kepada-Ku"

Tujuan kedua, adalah manusia diciptakan sebagai wakil Tuhan (khalifah) di muka bumi seperti dalam surat Al-Baqarah ayat 30. Tujuan ketiga, manusia diciptakan untuk membentuk masyarakat manusia yang saling kenal-mengenal, hormat menghormati dan tolong menolong antara satu dengan yang lain (QS alHujurat: 13).

\section{B. Fungsi Manusia}

manusia adalah makhluk fungsional dan bertanggungjawab. Artinya manusia berfungsi terhadap diri pribadinya, berfungsi terhadap masyarakat, berfungsi terhadap lingkungan, dan berfungsi terhadap Allah Sang Pencipta Manusia. (Q.S. AlMukminun:115).

\section{Manusia dan Pendidikan}

Menurut Langgulung dalam Hasan (2010:111) manusia pada hakikatnya diciptakan untuk mengembang tugastugas pengabdian kepada Penciptanya. Agar tugas yang dimaksud dapat dilaksanakan dengan baik, maka Sang Pencipta telah menganugrahkan kepada manusia seperangkat potensi yang dapat ditumbuhkembangkan. Potensi yang siap pakai tersebut dianugrahkan dalam bentuk kemampuan dasar, yang hanya mungkin berkembang secara optimal melalui bimbingan dan arahan yang sejalan dengan petunjuk sang Penciptanya.

\section{Pendidikan Agama Islam}

Menurut Mustofa Amin sebagaimana yang dikutip Ramayulis (1998:25) bahwa tujuan pendidikan Islam adalah mempersiapkan seseorang bagi amalan dunia dan akhirat. Abdullah Fayad dikutip Ramayulis (1998:26) menyatakan bahwa pendidikan Islam mengarah pada dua tujuan: (1) Persiapan untuk hidup akhirat; dan (2) Membentuk 
perorangan dengan ilmu pengetahuan dan keterampilan untuk menunjang kesuksesannya hidup di dunia.

\section{E. Komunitas}

Durkheim menjelaskan bahwa dalam membahas komunitas, diperkenalkan 2 konsep penting yakni kesadaran kolektif dan solidaritas sosial. Kesadaran kolektif dijabarkan berdasarkan katanya. Kesadaran atau conscience adalah suara hati yang mengingatkan bahwa seseorang terlibat secara kolektif dan menentukan apa yang baik dan yang buruk, sedangkan koletif menunjuk kepada pengertian kelompok yang luas seperti keluarga, kelompok studi, kerukuran, kelompok musik dan sebagainya. Sehingga, kesadaran kolektif adalah adanya perasaan dalam suatu komunitas tertentu yangn juga membuat individu-individu didalamnya merasakan adanya kewajiban moral untuk melaksanakan tuntutan yang diberikan oleh komunitas tersebut.

\section{F. Pengajian}

Handayani (2009:20-27) pengajian adalah penyelenggaraan atau kegiatan belajar agama Islam yang berlangsung dalam kehidupan masyarakat yang di bimbing atau diberikan oleh seorang guru ngaji (da'i) terhadap beberapa orang. Kegiatan tersebut diselenggarakan dalam waktu dan tempat tertentu, dengan tujuan agar orang-orang yang mengikuti dapat mengerti memahami dan keudian mengamalkan ajaran-ajaran agama Islam dalam kehidupannya.

\section{G. Kebutuhan dan Keinginan}

Adapun menurut Al-Syathibi, kebutuhan manusia terdiri dari tiga jenjang (Muflih, 2006:67), yaitu:

a. Kebutuhan Dharuriyat (Primer).

Kebutuhan dharuriyat merupakan satu kesatuan yang tidak dapat dipisahkan. Jika terabaikan maka akan merusak tatanan kehidupan manusia. Kebutuhan dharuriyat merupakan dasar asasi untuk terjaminnya kelangsungan hidup manusia. Lingkup kebutuhan dharuriyat ini ada lima macam, yaitu hal-hal yang berkaitan dengan pemeliharaan agama, jiwa, akal, keturunan dan harta.

b. Kebutuhan Hajjiyat (Sekunder)

Kebutuhan hajjiyat dimaksudkan untuk melengkapi kebutuhan dharuriyat. Kebutuhan hajjiyat dapat terpenuhi bila kebutuhan dharuriyat dapat terpenuhi.

c. Kebutuhan Tahsiniyat (Tersier) atau Kamaliyat (Pelengkap)

Kebutuhan tahsaniyat merupakan pelengkap dari kesenangan hidup. Kebutuhan ini dapat dipenuhi bila dharuriyat dan hajjiyat dapat terpenuhi dengan baik.

Pada hakikatnya adalah berupaya untuk memelihara kelima maqashid syariah guna mendapatkan gambaran koprehensif tentang tujuan syariah.

Keinginan merupakan kebutuhan yang dapat dipenuhi selain kebutuhan utama. Keinginan berasal dari hawa nafsu manusia yang menuntut untuk dipenuhi dan sifatnya tak terbatas. 


\section{H. Konsumsi}

Konsumsi merupakan kegiatan manusia dalam mencukupi kebutuhan maupun keinginan terhadap barang dan jasa. Chaney (2003:54) berpendapat konsumsi adalah seluruh tipe aktifitas sosial yang orang lakukan sehingga dapat dipakai untuk mencirikan dan mengenal mereka, selain (sebagai tambahan) apa yang mungkin mereka lakukan untuk hidup.

\section{Konsumsi dalam Islam}

Hidayat (2010:234) berpendapat tentang beberapa prinsip konsumsi Islam antara lain adalah:

1. Halal dan thayyib

manusia harus dapat adil dalam berkonsumsi, selain makanan yang halal juga menjauhi hal yang dilarang mnurut hukum Islam. Makanan yang halal akan berdampak pada keimanan seseorang, karena dengan mengkonsumsi makanan haram, pastilah dia teman setan. Dan setan merupakan musuh utama umat manusia. Makanan selain halal halal juga harus thayyib seperti pendapat Mannan (1997:45) yaitu makanan harus baik dan cocok untuk dimakan harus bersih dan bermanfaat karena kebersihan erupakan sebagian dari iman dan makanan yang bersih juga akan membuat tubuh menjadi sehat. Sehingga yang boleh dikonsumsi adalah makanan yang halal dan thayyib, maksudnya selain makanan tersebut bersifat halal, makanan juga harus bersifat baik untuk kehidupam manusia misalnya adalah baik untuk kesehatan tubuh.

2. Tidak boros dan Berlebih-lebihan

Islam memerintahkan tidak boleh berlebih-lebihan dan boros dalam setiap perbuatan termasuk dalam mengkonsumsi rezeki yang diberikan oleh Allah. Allah mengingatkan umat manusia untuk tidak boros dan berlebih-lebihan sesuai dengan firman Allah dalam surat Al-An'aam ayat 141.

3. Keseimbangan Konsumsi

Keseimbangan konsumsi merupakan alokasi pendapatan yang harus memperhatkan konsumsi dalam kegiatan sosial seperti zakat, infaq, maupun shadaqah (Hidayat 2010:239). Dalam Ekonomi Islam setiap pendapatan digunakan untuk memenuhi konsumsi (C), ZIS (Zakat, Infaq, Shadaqah). Dan ditabung (Nafik, 2009:27). Persamaan secara matematis dapat ditulis sebagai berikut:

$Y=C+Z I S+S$

$Y \quad$ : Pendapatan

ZIS : Zakat, Infaq, Shadaqah

C : Konsumsi

$S$ : Tabungan

(Nafik 2009:27)

\section{J. Perilaku Konsumsi}

Menurut Supranto dan Limakrisna (2007:4) perilaku konsumen merupakan tindakan yang langsung terlibat dalam mendapatkan, menggunakan (memakai, mengkonsumsi) dan menghabiskan 
produk (barang dan jasa) termasuk proses yang mendahului dan mengikuti tindakan ini.

\section{K. Perilaku Konsumsi dalam Perspektif Islam}

Perilaku Konsumsi dalam perspektif Islam mengajarkan tentang cara berkonsumsi dengan benar sesuai ajaran Al-Qur'an maupun hadits sehingga mampu memberikan petunjuk yang jelas tentang konsumsi, agar perilaku konsumsi manusia menjadi terarah (Hidayat 2010:229), Manusia dalam melakukan pemenuhan kebutuhan hidupnya dan adakalanya perilaku konsumsi juga merupakan kebiasaan dalam pemenuhan keinginan seseorang. Perilaku konsumsi yang seseuai dengan Islam akan menjamin kehidupan manusia yang adil dan sejahtera dunia dan akhirat.

Menurut Muflih, (2006:16), konsumsi seorang konsumen Muslim tidak hanya untuk materi saja, tetapi juga berbentuk zakat dan sedekah. Untuk sedekah saja disebutkan sebanyak 62 kali dalam AlQur'an, yang pertanda sangat penting dalam Islam karena pengeluaran konsumsi ini akan memperkuat sendi-sendi sosial masyarakat.

\section{Pemanfaatan Harta}

Manusia sebagai khalifah di muka bumi diberikan hak oleh Allah atas segala benda yang ada di sekitarnya, namun bukan hak untuk memilikinya secara mutlak, melainkan hak untuk mengelolanya dan mengambil manfaat dalam batas-batas tertentu. Pemberian hak oleh Allah atas benda tersebut harus diimbangi dengan kewajiban untuk mewujudkan kebaikan dan kemakmuran bersama.

Menurut Hidayat (2010:136-140) Cara memanfaatkan harta ada 3, yaitu:

1. Tidak boros dan tidak kikir.

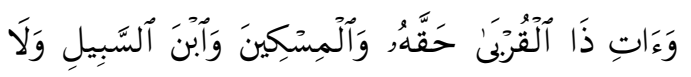

"Dan berikanlah kepada keluargakelvarga yang dekat akan haknya, kepada orang miskin dan orang yang dalam perjalanan dan janganlah kamu menghambur-hamburkan (hartamu) secara boros. Sesungguhnya pemborospemboros itu adalah saudara-saudara syaitan dan syaitan itu adalah sangat ingkar kepada Tuhannya." (QS. Al-Israa': 26-27).

2. Harus hati-hati dan bijaksana, serta menggunakan akal sehat dalam memanfaatkan harta.

3. Disalurkan melalui instrumen yang diatur dalam Islam seperti sedekah, infaq, hibah, kurban, zakat, dan wakaf.

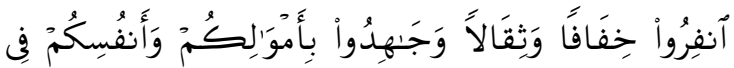

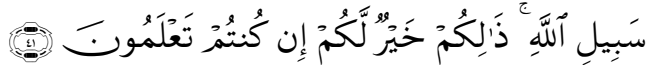
"Berangkatlah kamu baik dalam Keadaan merasa ringan maupun berat, dan berjihadlah kamu dengan harta dan dirimu di jalan Allah. yang demikian itu adalah lebih baik bagimu, jika kamu mengetahui." (QS. At-Taubah :41).

Semua yang bernyawa pasti mati. Kita tidak tahu kapankan kita akan mati. 
Kematian bisa saja setiap saat menjemput kita. Untuk itu 1/3 harta yang kita miliki apabila kita sedekahkan bisa sebagai bekal kita untuk dikahirat sedangkan 1/3 harta yang lain untuk memenuhi kebutuhan kita dan 1/3 harta yang lain untuk bekal kita bahwa kita perlu untuk melanjutkan hidup (investasi) sedangkan 1/3 harta yang kita sedekahkan tidak akan hilang, habis bahkan oleh Allah SWT akan dibalas berlipat ganda mulai 10 kali lipat bahkan sampai 700 kali lipat.

\section{Proposisi}

Pemahaman Islam tentang konsumsi berdampak pada perilaku anggota komunitas pengajian Al-Ikhlas cabang Rungkut Surabaya.

\section{N. Kerangka Berpikir}

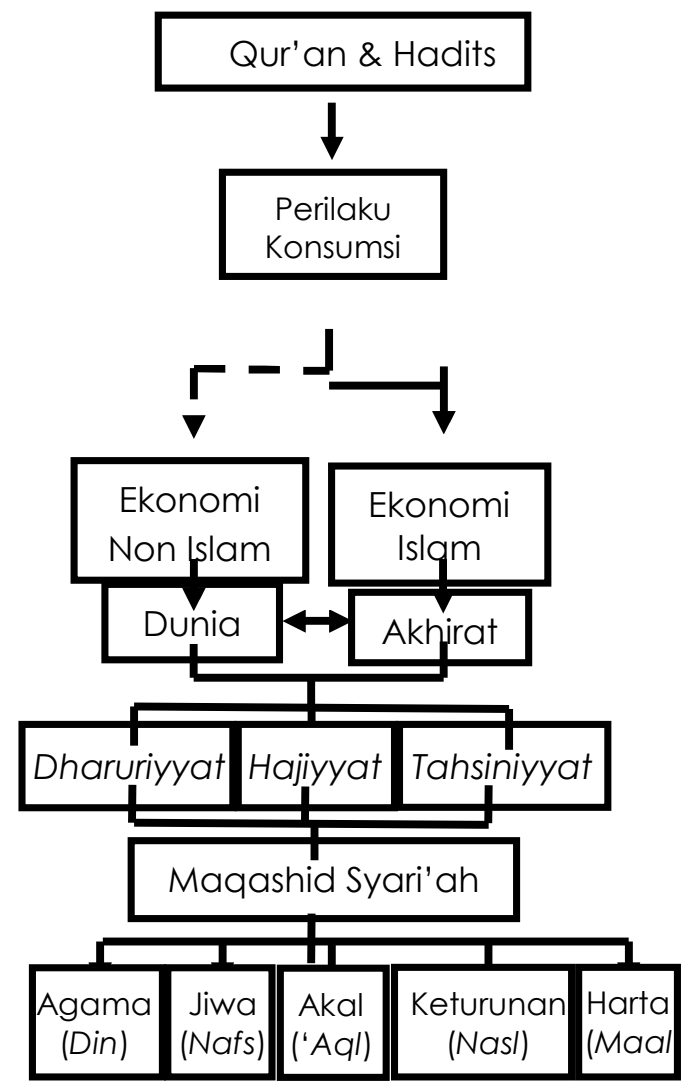

Keterangan :

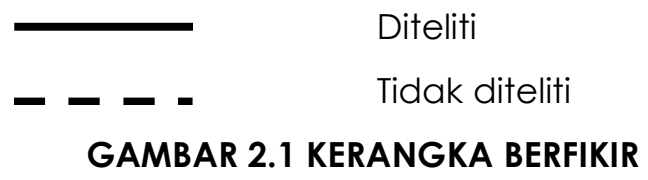

\section{METODE PENELITIAN}

\section{A. Pendekatan Penelitian}

Penelitian ini menggunakan pendekatan kualitatif. Menurut Yin (2002:2) pendekatan kualitatif adalah pendekatan dengan menggunakan data yang berupa kalimat tertulis atau lisan, peristiwaperistiwa, pengetahuan atau proyek studi yang bersifat deskriptif.

Strategi yang digunakan dalam penelitian ini adalah studi kasus. Menurut Yin (2009:1), studi kasus merupakan strategi yang lebih cocok bila pokok pertanyaan suatu penelitian berkenaan dengan how atau why, bila peneliti hanya memiliki sedikit peluang untuk mengontrol peristiwa-peristiwa yang akan diselidiki dan bilamana fokus penelitiannya terletak pada fenomena kontemporer (masa kini) di dalam konteks kehidupan nyata.

\section{B. Ruang Lingkup Penelitian}

Penelitian yang dimaksud adalah dalam rangka untuk menjawab rumusan masalah yaitu, "Bagaimana perilaku konsumsi anggota komunitas pengajian Al-Ikhlas Rungkut Surabaya?". Rumusan masalah tersebut menjadi acuan dalam penelitian ini. Ruang lingkup penelitian terbatas memfokuskan pada anggota aktif komunitas pengajian Al-lkhlas Rungkut Surabaya yang masih rutin 
mengikuti pengajian dan mencari jawaban bagaimana perilaku konsumsi yang dijalaninya.

\section{Jenis dan Sumber Data}

Jenis data yang digunakan dalam penelitian ini adalah data primer (utama) dan sekunder (penunjuang). Data primer adalah data yang diperoleh langsung dari sumbernya melalui wawancara dan observasi lapangan. Data primer merupakan data utama yang berasal dari hasil wawancara mendalam dan observasi langsung di lapangan. Data tersebut dikumpulkan dengan metode wawancara dimana metode ini memungkinkan peneliti bertatap muka langsung dengan informan untuk menggali informasi dengan lebih mendalam sehingga dapat dipertanggung jawabkan validitas datanya.

\section{Unit Analisis}

Unit analisis dari penelitian ini adalah anggota pengajian Al-Ikhlas Rungkut Surabaya. Penentuan informan dalam penelitian ini menggunakan teknik purposive untuk menentukan informan dari penelitian. Alasan penelitian ini menggunakan teknik purposive, yakni dalam pengambilan informan peneliti memilih orang atau individu yang dianggap paling tahu tentang apa yang diharapkan mengenai topik yang diteliti, dalam hal ini yakni anggota pengajian AlIkhlas Rungkut Surabaya.

\section{E. Teknik Analisis Data}

Teknik analisis penelitian ini adalah pendekatan analisis kualitatif deskriptif. Analisis tersebut bertujuan menganalisis data studi kasus dengan membuat penjelasan (naratif) dan menggambarkan (deskripsi) kasus yang bersangkutan dan membuktikan proposisi teoritis yang telah dibuat.

\section{HASIL ANALISIS DAN PEMBAHASAN}

A. Pemenuhan Kebutuhan Dharuriyyat, Hajiyyat, dan Tahsiniyyat dalam Pemeliharaan Agama, Jiwa, Akal,

\section{Keturunan dan Harta}

Dari hasil wawancara dapat diketahui bahwa para anggota komunitas pengajian yang diteliti secara keseluruhan, sebagian besar telah memenuhi kebutuhan yang dicontohkan oleh peneliti mulai dari terpenuhinya kebutuhan dharuriyyat, hajiyyat, dan tahsiyyat dalam pemeliharaan agama, jiwa, akal, keturunan dan harta.

Dapat dijabarkan dalam pembahasan kali ini, bahwa para anggota komunitas pengajian yang diteliti secara keseluruhan telah memenuhi kebutuhan yang dicontohkan oleh peneliti mulai dari terpenuhinya kebutuhan dharuriyyat, hajiyyat, dan tahsiyyat dalam pemeliharaan agama, jiwa, akal, keturunan dan harta. Hanya saja di tingkat dharuriyyat 7 (tujuh) anggota yang belum melaksanakan ibadah haji sebagai bentuk pemeliharaan agama dikarenakan keterbatasan biaya dan juga karena suatu kondisi tertentu dan juga dalam 
pemeliharaan akal, 2 (dua) anggota pernah mengkonsumsi minuman alkohol dikarenakan tuntutan pendidikan serta keinginananya untuk mencoba. Pemeliharaan harta tingkat hajiyyat, belum sepenuhnya dipenuhi oleh anggota yaitu menghindarkan diri dari transaksi ribawi yang dilarang oleh Islam seperti menabung di bank konvensional dan melakukan kredit atau hutang yang menggunakan bunga, namun hanya 1 (satu) anggota yang menjalankannya dengan tidak pernah menggunakan layanan keuangan konvensional. Di tingkat tahsiniyyat 4 (empat) anggota juga belum mengenakan hijab yang berkenaan dengan etika dalam Islam bagi seorang muslimah agar menutup auratnya. Kemudian dalam pemeliharaan akal juga sebagian besar anggota pengajian belum menghindarkan diri dari hal yang tidak berfaedah seperti gemar menonton acara infotaiment atau gosip di televisi, kecuali 3 (tiga) anggota yang telah melaksanakannya.

\section{B. Pengamalan Konsumsi Islami}

Untuk menjadikan manusia memiliki akhlak yang baik dan ilmu pengetahuan yang baik, peranan pengamalan ajaran agama Islam merupakan salah satu hal yang tidak dapat diabaikan dan menjadi suatu prioritas karena wajib hukumnya bagi seorang muslim untuk mengamalkan suatu perintah yang telah ia ketahui.

Dari hasil analisis tingkat pengamalan konsumsi Islami, dapat diketahui bahwa 35\% informan memiliki tingkat pengamalan atau ketaatan kepada ajaran agama tentang konsumsi islami yang sedang. Hal ini dikarenakan masih adanya informan yang masih belum bisa berhemat atau dapat dikatakan boros dan berlebih-lebihan serta mengkonsumsi barang-barang yang pada akhirnya mubadzir atau tidak terpakai. Sedangkan $65 \%$ informan lainnya memiliki tingkat pengamalan konsumsi Islami yang tinggi dikarenakan masih dapat mengontrol pengeluaran mereka dengan mengontrol hawa nafsu mereka untuk memenuhi keinginan. Namun, dari keseluruhan informan masih banyak yang belum dapat menghindarkan diri dari transaksi ribawi dengan menggunakan layanan perbankan konvensional dan melakukan kredit atau akad yang tidak sesuai dengan syariah Islam.

\section{Perilaku Konsumsi Berdasarkan Keaktifan}

Dari hasil analisis tingkat pengamalan konsumsi berdasarkan keaktifan informan dalam mengikuti kegiatan pengajian di pengajian Al-Ikhlas Rungkut Surabaya, didapatkan hasil bahwa dari 15 informan yang aktif terdapat 6 (enam) informan dengan tingkat pengamalan konsumsi Islami yang sedang dan 9 (sembilan) informan dengan tingkat pengamalan konsumsi Islami yang tinggi. Sedangkan dari 5 (lima) informan yang tidak aktif dalam kegiatan pengajian di Al-ikhlas Rungkut Surabaya, 1 (satu) informan memiliki tingkat 
pengamalan konsumsi islami yang sedang dan 4 (empat) informan memiliki tingkat pengamalan konsumsi islami yang tinggi. Hal ini dikarenakan kemungkinan para anggota pengajian yang terkategorikan tidak aktif mendapatkan ilmu agama di luar pengajian Al-Ikhlas seperti mengikuti kegiatan pengajian lain yang berasal dari media dan juga ceramah keagamaan sehingga ilmu agama Islam pun tetap dapat mereka dapatkan.

Dapat disimpulkan bahwa keaktifan informan dalam mengikuti kegiatan pengajian berdampak pada pengamalan konsumsi Islami yang dijalaninya. Hal itu dikarenakan dengan mereka aktif mengikuti kegiatan pengajian, maka pengetahuan mereka akan agama Islam akan bertambah, sehingga akan mempengaruhi perilaku mereka dalam mengamalkan ajaranajaran agama Islam termasuk dalam hal konsumsi sesuai Islam

\section{Perilaku Konsumsi Berdasarkan}

\section{Pemahaman Tentang Konsumsi Islami}

Dari hasil wawancara dapat diketahui bahwa masih banyak anggota pengajian yang belum terlalu mengetahui secara utuh tentang bagaimana konsumsi yang baik sesuai Islam. 12 dari 20 informan masih terkategorikan memiliki pemahaman yang sedang tentang konsumsi Islami. Secara keseluruhan informan mengetahui tentang bagaimana cara berkonsumsi yang baik, namun tidak mengetahui secara spesifik dan lengkap. Sebagian besar dari informan hanya mengetahui hal tersebut berdasarkan pengalaman yang mereka jalani selama ini. Hanya delapan orang yang dapat menjelaskan secara spesifik dan paling mendekati tentang konsumsi sesuai Islam yang benar dan terkategorikan memiliki pemahaman yang tinggi. Sementara tidak ada informan yang terkategorikan berpemahaman rendah dikarenakan beberapa materi pernah mereka dapatkan di pengajian.

Hasil analisis dapat dilihat bahwa sebanyak 4 (empat) informan yang memiliki tingkat pemahaman konsumsi Islam yang sedang, memiliki tingkat pengamalan konsumsi Islamnya yang sedang pula. Sama halnya dengan 5 (lima) informan yang memiliki tingkat pemahaman konsumsi Islam yang tinggi, memiliki tingkat pengamalan konsumsi Islami yang juga timggi. Namun hasil terbanyak dari 20 informan yaitu 8 (delapan) informan yang memiliki tingkat pemahaman konsumsi Islam yang sedang, ternyata memiliki tingkat pengamalan konsumsi Islam yang tinggi. Begitu pula sebaliknya, terdapat 3 (tiga) informan yang memiliki tingkat pemahaman konsumsi Islam yang tinggi, ternyata memiliki tingkat pengamalan konsumsi Islam yang sedang. Dari hasil diatas dapat disimpulkan bahwa tingkat pemahaman tentang konsumsi Islam seseorang dapat berdampak pada tingkat pengamalan konsumsi Islami orang tersebut dikarenakan hasil yang di dapat berdasarkan sebagian besar informan memiliki tingkat pengamalan atau perilaku konsumsi Islam yang tinggi. 
Hal ini juga menandakan bahwa adanya perubahan perilaku konsumsi para informan ke arah yang lebih baik dengan mereka mengikuti kegiatan pengajian. Tidak terlalu banyak perubahan perilaku konsumsi secara spesifik dari apa yang telah didapat informan dengan mengikuti kegiatan pengajian dikarenakan sebagian besar prinsip konsumsi Islami telah dijalankan informan sejak dahulu. Hal-hal yang menjadi perubahan pada hidup mereka dengan mengkuti kegiatan pengajian adaah lebih pada perubahan spiritual mereka dalam hal beribadah dan juga semakin dekat kepada Allah SWT. Hanya sebagian kecil yang mengalami perubahan dalam berperilaku konsumsi Islami seperti mulai berpindah dari layanan kevangan konvensional menjadi layanan kevangan syariah, dan juga ulai dapat mengontrol keinginan mereka dalam berbelanja baang-barang yang kurang bermanfaat.

\section{E. Perilaku Konsumsi Komunitas Pengajian}

\section{Al-Ikhlas Rungkut Surabaya}

Berbicara mengenai perilaku konsumsi komunitas pengajian, bagi sebagian orang mungkin hal ini terlalu penting dan terkesan biasa saja seperti perilaku konsumsi setiap manusia pada umumnya. Mereka akan beranggapan bahwa konsumsi yang dijalani hanya seputar pemenuhan kebutuhan sehari-hari saja dan bagaimana hidupnya akan bahagia dengan tercukupinya semua hal yang diinginkannya. Tapi tidak semudah itu untuk umat Islam khususnya untuk komunitas pengajian yang sedang mempelajari tentang agama Islam. Perilaku konsumsi yang sesuai Islam sudah diatur oleh Allah dalam Al-Qur'an dan AlHadits bertujuan untuk meluruskan hidup manusia agar tidak terlena dengan kenikmatan dunia. Ada batasan-batasan konsumsi yang harus dijalani oleh manusia agar dapat menjaga dirinya dari keburukan atau dosa karena harta. Tanggung jawab yang wajib umat muslim jalankan adalah ia harus mengamalkannya ketika ia mengetahui apa yang diperintahkan dan dilarang oleh Allah.

Hasil penelitian menunjukkan bahwa kegiatan pengajian berdampak pada perilaku konsumsi yang dijalani oleh sebagian besar anggota komunitas pengajian Al-Ikhlas Rungkut Surabaya dengan lebih memperhatikan dan mengedepankan konsumsi sesuai Islam, yaitu: 1) Halal dan thayyib, 2) Tidak boros dan berlebih-lebihan, dan 3) Seimbang antara konsumsi dunia dan akhirat. Seluruh anggota pengajian telah mengetahui tentang hukum halal-haramnya dalam mengkonsumsi suatu makanan dengan memperhatikan setiap kehalalan makanan yang mereka makan dari zat dan proses pengolahannya serta memperhatikan label halal dari setiap yang mereka konsumsi. Tidak lupa mereka selalu mengkonsumsi makanan yang thayyib atau baik yaitu yang menyehatkan demi terpeliharanya kesehatan tubuh. Kemudian, dalam 
prinsip untuk tidak boros dan berlebihlebihan, hampir seluruh anggota mengkonsumsi suatu barang sesuai dengan kebutuhan dan memprioritaskan terlebih dahulu kebutuhan daripada keinginannya, namun beberapa anggota dapat dikatakan boros dan berlebihlebihan dikarenakan mengkonsumsi barang yang berlebih serta tidak sesuai disebabkan keinginan mereka yang belum dapat terkontrol dengan baik meskipun itu tidaklah menimbulkan kemudharatan baginya. Beberapa dari mereka juga memilih untuk membeli barang bermerek mahal dikarenakan kualitas serta fungsi yang menurut mereka itu penting. Keseimbangan konsumsi dunia dan akhirat juga telah dijalankan dengan baik oleh seluruh anggota pengajian dengan tidak lupa mengeluarkan kewajibannya dalam berzakat, infaq, dan shadaqah serta masih dapat mengalokasikan sebagian harta mereka untuk di tabung sebagai simpanan apabila suatu saat ada keperluan mendadak.

Kemudian, para anggota komunitas pengajian yang diteliti secara keseluruhan juga telah menunjukkan perilaku konsumsi sesuai dengan syari'at Islam dengan memenuhi kebutuhan dharuriyyat, hajiyyat, dan tahsiyyat dalam pemeliharaan agama, jiwa, akal, keturunan dan harta dengan baik meskipun tidak secara sempurna.

\section{SIMPULAN}

1. Kegiatan pengajian berdampak pada perilaku konsumsi yang dijalani oleh sebagian besar anggota komunitas pengajian Al-Ikhlas Rungkut Surabaya dengan lebih memperhatikan dan mengedepankan konsumsi sesuai Islam, yaitu: 1) Halal dan thayyib, 2) Tidak boros dan berlebih-lebihan, dan 3) Seimbang antara konsumsi dunia dan akhirat. Namun beberapa anggota dapat dikatakan boros dan berlebihlebihan dikarenakan mengkonsumsi barang yang berlebih serta tidak sesuai dengan fungsinya hingga pada akhirnya menjadi mubadzir dan sia-sia, hal itu disebabkan keinginan mereka yang belum dapat terkontrol dengan baik meskipun itu tidaklah menimbulkan kemudharatan baginya.

2. Perilaku konsumsi komunitas pengajian Al-Ikhlas Rungkut Surabaya dalam pemenuhan kebutuhan dharuriyyat, tahsiniyyat dan hajiyyat demi terpeliharanya agama, jiwa, akal, keturunan dan harta telah dapat dijangkau dan terpenuhi dengan baik meskipun tidak secara sempurna.

3. Keaktifan anggota pengajian Al-Ikhlas dalam mengikuti kegiatan pengajian berdampak pada perilaku konsumsi Islami yang dijalaninya. Hal itu dikarenakan dengan mereka aktif mengikuti kegiatan pengajian, maka pengetahuan anggota pengajian akan agama Islam akan bertambah, sehingga akan mempengaruhi perilaku mereka dalam mengamalkan ajaran- 
ajaran agama Islam termasuk dalam hal konsumsi sesuai Islam.

4. Tingkat pemahaman komunitas pengajian Al-Ikhlas Rungkut Surabaya tentang konsumsi Islam berdampak pada tingkat pengamalan konsumsi yang sesuai dengan Islam dikarenakan sebagian besar anggota pengajian memiliki tingkat pemahaman konsumsi Islam yang tinggi.

\section{DAFTAR PUSTAKA}

Achmadi. 2005. Ideologi Pendidikan Islam. Yogyakarta : Pustaka Pelajar.

Chaney, David. 2003. Lifestyles: Sebuah Pengantar Komprehensif. Yogyakarta. Jalasutra.

Departemen Agama RI. 2011. Al-Qur'an Terjemahan. Bandung: Diponegoro Handayani, Endang Sih. 2009. Motivasi Ibuibu Rumah Tangga Mengikuti Pengajian Muslimat NU di Ranting Troso Kec. Karanganom Kab. Klaten. Yogyakarta. Universitas Islam Negeri Sunan Kalijaga Yogyakarta. (Online). http://digilib.uin-suka.ac.id (diakses 13 November 2013, jam 23.00).

Hidayat, Mohammad. 2010. An Introduction to The Sharia Economic (Pengantar Ekonomi Syariah). Jakarta : Zikrul.

Karim, Adiwarman A. 2007. Ekonomi Mikro Islami. Jakarta: PT Raja Grafindo.

Langgulung, Hasan. 1986. Manusia dan Pendidikan. Jakarta: Al Husna.
Mannan, Mohammad Abdul. 1996. Financing Development in Islam. Jeddah : IRTI.

Muflih, Muhammad. 2006. Perliaku Konsumen dalam Perspektif IImu Ekonomi Islam. Jakarta: PT. Grafindo Persada.

Nafik, Muhammad. 2009. Ekonomi ZISWAQ. Surabaya: IFDI.

Ramayulis. 1994. IImu Pendidikan Islam. Jakarta: Kalam Mulia.

Sukadi, Hananda Dwi. 2011. Pemahaman Perilaku Konsumsi Islam Sumber Daya Insani Departemen Ekonomi Syariah Universitas Airlangga. Surabaya: Universitas Airlangga. (Skripsi Tidak Diterbitkan).

Sugiyono. 2011. Metode Penelitian Pendidikan: Pendekatan Kuantitatif, Kualitatif, dan R\&D. Bandung: Alfabeta.

Supranto, J. dan Nandan Limakrisna. 2007. Perilaku Konsumen dan Strategi Pemasaran untuk Memenangkan Persaingan Bisnis. Edisi Pertama. Jakarta: Mitra Wacana Media. 